\title{
Rozrost terytorialny dużych miast w Polsce Territorial development of large cities in Poland
}

\author{
Robert Szmytkie (1) \\ Uniwersytet Wrocławski \\ Instytut Geografii i Rozwoju Regionalnego \\ PI. Uniwersytecki 1, 50-137 Wrocław \\ robert.szmytkie@uwr.edu.pl
}

\begin{abstract}
Zarys treści. Głównym celem opracowania była identyfikacja procesu rozrostu terytorialnego dużych miast w Polsce na przykładzie Wrocławia, Krakowa i Warszawy. Analiza zmian granic administracyjnych miasta, zmian gęstości zaludnienia oraz rozwoju zabudowy wykazała pewną specyfikę rozrostu terytorialnego dużych miast oraz podobieństwo procesów osadniczych w różnych okresach historycznych. Pozwoliło to na identyfikację określonych prawidłowości rozwoju, które z uwagi na ich powtarzalność, wskazują na cykliczny charakter procesów. Specyfikę rozrostu przestrzennego dużych miast można wyrazić w następujący sposób: każdy okres rozwoju społeczno-gospodarczego miasta przyczynia się do wzrostu gęstości zaludnienia w jego granicach, a następnie do wylania się miasta na obszar najbliższego otoczenia (strefy podmiejskiej). Obszar ten stanowi faktycznie przedłużenie miasta i z czasem zostaje wcielony w jego granice administracyjne. Poszerzenie granic miasta powoduje zwykle spadek gęstości zaludnienia w jego nowych granicach. Każdy kolejny okres prosperity miasta inicjuje kolejny cykl rozwoju przestrzennego.
\end{abstract}

Słowa kluczowe: rozrost terytorialny, rozwój przestrzenny, cykle rozwojowe, duże miasta. Keywords: territorial expansion, spatial development, development cycle, large cities.

\section{Wstęp}

Rozwój przestrzenny miast jest jednym z najbardziej jaskrawych przejawów urbanizacji (por. Pacione, 2001; Barras, 2009; Hall i Barrett, 2012). Wzrost liczby ludności powoduje bowiem rozwój zabudowy, a tym samym powierzchniowe rozrastanie się miast. Wraz z postępem tego procesu miasta zaczynają wylewać się poza swoje granice, z czasem wcielając w swój obręb silnie z nim powiązane obszary podmiejskie. Co więcej, zjawisko to jest charakterystyczne nie tylko dla miast współczesnych, ale również miało ono miejsce w okresach wcześniejszych, np. w średniowieczu (Sjöberg, 1960; De Long i Shleifer, 1993; Morris, 2013) czy dobie przemysłowej (Lawton, 1972; Hall, 1998; Robson, 2012; Krzysztofik, 2014). We współczesnych miastach zasięg wyznaczony jego granicami administracyjnymi często rozmija się z faktycznym zasięgiem przestrzennym wyznaczonym w oparciu o inne aspekty urbanizacji. W dotychczasowych badaniach uwaga badaczy skupiała się głównie na zagadnieniu rozwoju przestrzennego miast (Arnott, 1980; Robson, 2012), w szczególności zmian gęstości zaludnienia w relacji centrum-obszary podmiejskie analizowanych w kontekście zaawansowania procesów urbanizacji (Clark, 1951; Newling, 1966; Klaassen i Paelinck, 1979; Anas et al., 1998; i prace późniejsze). Niewiele opraco- 
wań dotyczyło z kolei rozrostu terytorialnego miast, a także zależności między rozrostem terytorialnym a rozwojem przestrzennym miast (Mydel, 1979; Semotanová, 2010; Motak, 2012). Zagadnienie rozwoju przestrzennego (rozrostu terytorialnego) dużych miast w Europie Środkowo-Wschodniej było z kolei dyskutowane na przykładzie: Berlina (Escher, 1985; Elkins i Hofmeister, 1988), Budapesztu (Enyedi i Szirmai, 1992) czy Pragi (Semotanová, 2010). Osobną grupę stanowią prace poruszające zagadnienie zmian granic administracyjnych miast w Polsce w okresie powojennym jako jednego z przejawów urbanizacji (Szymańska et al., 2006, 2009; Szmytkie, 2019).

Inspiracją do podjęcia badań w tym zakresie stały się obserwacje dotyczące specyfiki rozrostu terytorialnego Wrocławia i innych dużych miast w Polsce, analiza których wykazuje pewne podobieństwo procesów osadniczych w różnych okresach historycznych. Pozwala to na identyfikację pewnych prawidłowości rozwoju, które z uwagi na ich powtarzalność, wskazują na cykliczny charakter procesów rozwojowych. Na wstępie należałoby również wyjaśnić dwa pojęcia kluczowe z punktu widzenia rozważań dyskutowanych w niniejszej pracy, tzn. pojęcia rozrostu terytorialnego i rozwoju przestrzennego miasta. Pojęcia te dość często traktowane są jako synonimy, jednak odbiegają od siebie znaczeniowo jeśli chodzi o ich relację z przebiegiem granic administracyjnych miasta. Rozrost terytorialny miasta (także zmiany terytorialne) jest to bowiem wzrost (zmiana) powierzchni miasta, związany z poszerzeniem (lub zawężeniem) jego granic administracyjnych (zmiana de jure), natomiast rozwój przestrzenny miasta następuje w wyniku rozwoju terenów zurbanizowanych (zwłaszcza zabudowanych) w obrębie granic bądź w bezpośrednim sąsiedztwie miasta (i wtedy oznacza rozwój strefy podmiejskiej), co jednak nie musi powodować zmiany jego granic administracyjnych (zmiana de facto).

Na potrzeby pracy przyjęto następującą hipotezę badawczą: rozrost terytorialny miasta następuje stopniowo (w sposób pulsacyjny), a każde poszerzenie jego granic administracyjnych przebiega według określonego schematu i jest ono następstwem okresu rozwoju społeczno-gospodarczego miasta. Uzupełnieniem dla tak postawionej hipotezy są 4 zasadnicze pytania badawcze: [1] Jakie relacje występują między rozwojem przestrzennym i rozrostem terytorialnym dużych miast? [2] Jakie są główne procesy budujące i niszczące w rozwoju przestrzennym miasta? [3] Jakie są społeczne, ekonomiczne, polityczne i technologiczne uwarunkowania przyczyniające się do rozwoju przestrzennego dużych miast? [4] W jaki sposób na rozwój przestrzenny miast oddziałują siły odśrodkowe i dośrodkowe? W pracy podjęto ponadto problem zachodzących współcześnie procesów suburbanizacji oraz granic administracyjnych (zasięgu przestrzennego) miasta. Postępowanie badawcze przyjęte na potrzeby niniejszego opracowania ma charakter studium przypadku, a jego głównym celem była identyfikacja procesu rozrostu terytorialnego dużych miast w Polsce na przykładzie Wrocławia, Krakowa i Warszawy. Wybór tych miast nie był przypadkowy. Miasta te są bowiem historycznie ukształtowanymi ośrodkami regionalnymi (odpowiednio jako historyczne stolice Śląska, Małopolski i Mazowsza ${ }^{1}$ ), obecnie są stolicami województw i ośrodkami rdzeniowymi aglomeracji monocentrycznych, a zarazem zaliczane są do grona ośrodków metropolitarnych (Markowski i Marszał, 2006). Należy również zwrócić uwagę, że rozwój (w tym również rozrost terytorialny) form policentrycznych (miast stanowiących część aglomeracji policentrycznych i miast-zlepieńców) przebiega w inny sposób (Krzysztofik, 2014; Szmytkie i Krzysztofik, 2019).

\footnotetext{
1 Przy czym Wrocław i Kraków ośrodkami regionalnymi stały się już w średniowieczu, a Warszawa pod koniec XV w.
} 


\section{Zarys teorii}

W ujęciu teoretycznym rozwój przestrzenny i/lub terytorialny miast należy rozpatrywać jako przykład procesu ekspansji (Haggett, 1972). Według Burgessa (1935) typowy proces ekspansji miasta może być wyrażony przez serię koncentrycznych pierścieni, obejmujących zarówno sukcesywne strefy rozbudowy miasta, jak i różne rodzaje obszarów zróżnicowanych w procesie ekspansji przestrzennej. Wydaje się, że aż do XIX w. rozwój przestrzenny miast przebiegał głównie koncentrycznie, a jedyne modyfikacje wynikały z topografii terenu. Według Halla i Barrett (2012) zewnętrzna ekspansja miasta przemysłowego obejmowała zabudowę mieszkaniową o odrębnej fizjonomii, powstającą w wyniku kolejnych faz ekspansji zabudowy podmiejskiej, a jej różnorodność wynikała z różnych okresów, w których rozwijały się dane przedmieścia (Harris i Larkham, 1999). Wraz z postępem technologicznym w transporcie rozwój przestrzenny miast stał się bardziej sektorowy, nawiązując do przebiegu głównych ciągów komunikacyjnych (Hoyt, 1939; Whitehand, 1972; Pacione, 2001; Hall i Barrett, 2012). Co więcej, rozwój przemysłu w XIX w. sprzyjał rozwojowi policentrycznemu, komplikując tym samym kształtowanie się struktur przestrzennych miast (Krugman, 1997; Anas et al., 1998; Krzysztofik et al., 2016).

Zagadnienie struktur przestrzennych dużych miast zwykle rozpatrywane jest w ujęciu statycznym, a istotą badań jest wypracowanie uniwersalnego lub typowego dla danego regionu modelu struktury przestrzennej miasta. Do najważniejszych ujęć modelowych należy zaliczyć klasyczne modele szkoły chicagowskiej, tzn. model strefowo-koncentryczny (Burgess, 1925), model (klinowy) sektorowy (Hoyt, 1939) i model (policentryczny) wieloośrodkowy (Harris i Ullman, 1945), a także ich późniejsze modyfikacje, jak np. model rdzeniowo-ramowy (Boyce i Horwood, 1959), model Manna (1965), model Reesa (1970), model Hopkinsona (Daniel i Hopkinson, 1989), model rozwoju dużych miast Ameryki Łacińskiej (Borsdorf et al., 2007) czy modele struktury przestrzennej miast w różnych regionach świata zaproponowane przez Stewiga (1983). Z polskich opracowań na szczególną uwagę zasługuje model struktury przestrzennej średnich miast ośrodków wojewódzkich (Werwicki, 1973).

Zagadnienie rozwoju przestrzennego miast w większości opracowań analizowane jest w kontekście zmian gęstości zaludniania w zależności od odległości od centrum. Rozważania w tym zakresie rozpoczęła praca Clarka (1951), który stwierdził, że gęstość zaludnienia w zespole miejskim gwałtownie maleje wraz z odległością od centrum, a także, że profile gęstości zaludnienia zmieniają się w czasie. Problem zmian w przestrzennym rozmieszczeniu ludności był przedmiotem licznych opracowań, z których na szczególną uwagę zasługują prace Newlinga (1969), Halla (1971) oraz Klaassena i Paelincka (1979). Newling (1969) przedstawił teoretyczne profile gęstości zaludnienia dla 4 wyróżnionych przez siebie faz rozwoju: młodości, wczesnej dojrzałości, późnej dojrzałości i starości. Hall (1971), a następnie Klaassen i Paelinck (1979) analizowali rozwój miast i ich stref podmiejskich w kontekście zaawansowania procesów urbanizacji (wyróżniając cztery fazy: urbanizacji, suburbanizacji, dezurbanizacji i reurbanizacji), skupiając się na relacjach między zmianami demograficznymi zachodzącymi w regionie miejskim oraz skutkach przestrzennych tych procesów (koncentracja i dekoncentracja) (Grzeszczak, 1996). Prace te stały się punktem wyjścia dla dalszych rozważań analizujących zmiany gęstości zaludnienia wraz z rozwojem przestrzennym miasta (zespołu miejskiego). 
Pewną próbą powiązania zmian gęstości zaludnienia z rozwojem przestrzennym jest koncepcja falowego rozwoju miasta zaproponowana przez Korcellego (1969), który badał rozwój struktury przestrzennej obszarów metropolitarnych Kalifornii. Analiza zmian gęstości zaludnienia wykazała występowanie kolejnych fal wzrostu, a w obrębie każdego z cykli faz: penetracji, inwazji, konsolidacji i nasycenia, a niekiedy też fazy dalszego powolnego wzrostu (tzw. pilling-up). Kolejne etapy rozchodzenia się innowacji w dziedzinie transportu wyznaczały odmienne modele rozwoju przestrzennego miast. Przebieg fal wzrostu może być zakłócany przez czynniki zniekształcające, w ramach których można wyróżnić: zmiany w czasie (okresy prosperity i kryzysów gospodarczych, zmiany technologiczne, zmiany w dochodach ludności, kataklizmy) i różnice w oporze lokalnym (pozytywne - korzyści położenia, przebieg granic administracyjnych, negatywne - bariery naturalne, bariery instytucjonalne). Ponadto Korcelli (1969) wyróżnił 3 zasadnicze procesy sukcesji przestrzennej związane z przesuwaniem sią fal wzrostu: [1] rozwój rozproszonego osadnictwa podmiejskiego na terenach poprzednio nieużytkowanych lub wykorzystywanych ekstensywnie, [2] przejście z użytkowania rolniczego, związanego z uprawą ziemi, lub osadnictwa rozproszonego na osadnictwo podmiejskie o luźnej zabudowie, [3] zastąpienie użytkowania typu podmiejskiego zabudową zwartą, głównie wielorodzinną z dużym udziałem przemysłu i handlu.

Znacznie mniej opracowań koncentruje się na zagadnieniu rozwoju miast w aspekcie przestrzennym, zwłaszcza w długim horyzoncie czasowym. Szczególnie interesujące w tym zakresie wydają się ujęcia teoretyczne, wskazujące na następstwo procesów rozwojowych i/lub na cykliczność rozwoju przestrzennego miast, wśród których można wymienić m.in.: [1] model rozwoju XIX-wiecznego miasta przemysłowego Lawtona (1973), [2] koncepcję cyklów budowlanych (building cycles) (Barras, 2009), [3] koncepcję przyrostu pierścieni obrzeży miejskich (tzw. fringe belts) Conzena (1960) i Whitehanda (1967; 1988) oraz [4] studia nad rozwojem struktury przestrzennej Krakowa (Mydel, 1979).

Model Lawtona (1973) opierał się na analizie rozwoju przestrzennego Liverpoolu w XIX w. Lawton zidentyfikował epizody rozwoju (prosperity) i zastoju gospodarczego w historii miasta. Koncentryczne pierścienie opisane w modelu (ryc. 1) wynikają z następujących po sobie cyklicznie faz ekspansji miasta, nawiązujących do okresów, w których jego gospodarka się rozwija. Okresy te można też interpretować jako cykle budowlane. Konsolidacja, a nawet stagnacja w rozwoju przestrzennym miasta odpowiada z kolei okresom recesji gospodarczej. W modelu Lawtona wcześniej istniejące wzorce użytkowania terenu przyczyniają się do różnic między poszczególnymi strefami - wsie i małe miasta mogą być wchłaniane (inkorporowane w granice miasta) w miarę jak postępuje rozwój gospodarczy i ekspansja przestrzenna miasta. Strzałki pokazują kierunek i względną siłę mobilności ludności do lub z miasta i w jego obrębie. Według Krzysztofika (2014) można je także interpretować jako oddziaływanie sił dośrodkowej i odśrodkowej, rozpatrywanych w kontekście przemieszczeń ludności, towarów lub powiązań społeczno-gospodarczych. Zdaniem Malisza (1966) motorem terytorialnego powiększania się aglomeracji są ruchy odśrodkowe, pod których wpływem poszczególne grupy jednostek ekologicznych przesuwają się w strefy zewnętrzne aglomeracji tym chętniej, im bardziej warunki w centrum stają się dla nich niedogodne.

Koncepcja cyklów budowlanych (building cycles) zakłada zmienną intensywność ruchu budowlanego oraz występowanie okresów intensywnego budownictwa mieszkaniowego (Barras, 2009). Isard (1942) wskazał na związek między cyklami budowlanymi a rozwojem transportu, a Riggleman (1933) na ich związek z ogólnymi cyklami koniunkturalnymi. Ba- 


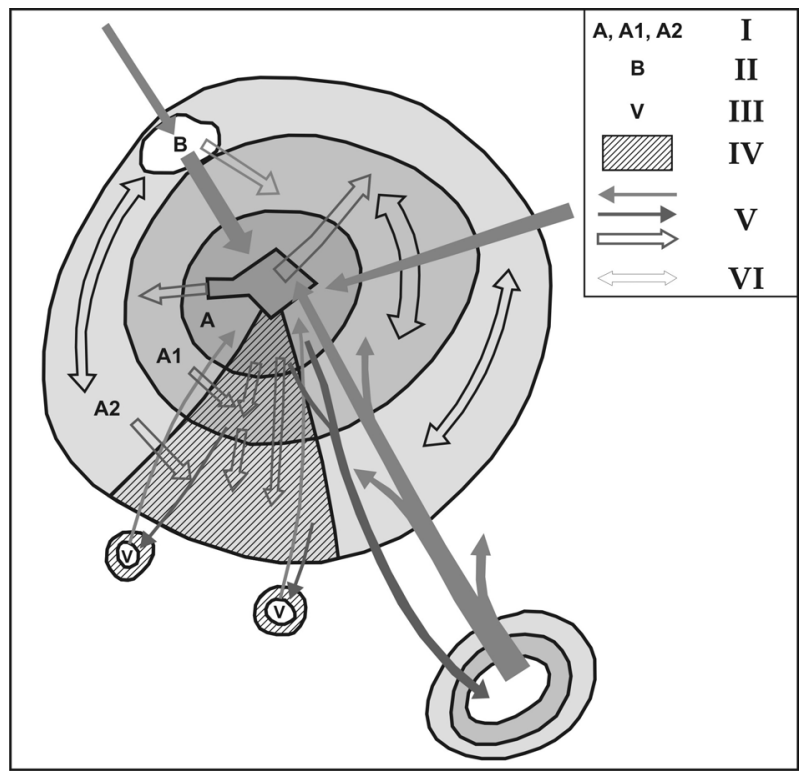

Ryc. 1. Model rozwoju przestrzennego miast w XIX w. wg R. Lawtona (1972)

I - etapy koncentrycznego rozwoju miasta, II - małe miasto wchłonięte w trakcie rozwoju przestrzennego dużego miasta, III - rozwój miejscowości podmiejskich, IV - sektor zamieszkania klasy średniej, V - akcja dośrodkowa i siły odśrodkowe, VI - ruchy śródmiejskie.

Model of urban spatial development in the 19th century, after R. Lawton (1972)

Opracowanie własne na podstawie Lawton (1972).

dania Whitehanda (1972) wykazały natomiast wpływ cyklów budowlanych na ogólne kierunki rozwoju przestrzennego miasta. Występowanie tych związków potwierdzają również badania innych autorów (por. Barras, 2009). Barras (2009) w przypadku miast brytyjskich wyróżnił sześć zasadniczych cyklów budowlanych, związanych z: [1] pierwszą rewolucją przemysłową (1785-1856), [2] drugą rewolucją przemysłową (1856-1888), [3] okresem rozwoju elektryczności (1888-1918), [4] okresem międzywojennym (1918-1944), [5] powojennym boomem konsumenckim (1944-1981) i [6] okresem rozwoju technologii informatycznych (1981-2008?).

Koncepcję przyrostu pierścieni obrzeży miejskich (tzw. fringe belts) (Baranowska, 2007) po raz pierwszy została przedstawiona przez Louisa (1936) na przykładzie rozwoju przestrzennego Wielkiego Berlina. Badania nad tą koncepcją rozwinęli Conzen (1960) i Whitehand $(1967,1988)$, który powiązał przyrost pierścieni obrzeży miejskich z cyklami budowlanymi i teorią renty gruntowej (bid rent theory), czego syntezę stanowi model rozwoju fringe belts (ryc. 2). W myśl koncepcji fringe belts należy rozumieć jako system względnie koncentrycznych, oddzielonych od siebie pierścieni wyróżniających się ekstensywnym użytkowaniem terenu, sukcesywnie zapisujących się w przestrzeni miejskiej. Powstają one w wyniku czasowego postoju bądź powolnego rozwoju peryferyjnych obszarów, co związane jest z pojawieniem się przeszkód (fixation lines) (Baranowska, 2007). Prace innych autorów koncentrują się na zagadnieniu identyfikacji fringe belts w strukturze przestrzennej wybranych miast (por. np. Barke, 1976; Carter i Wheatley, 1979; Ducom, 2003; Ünlü, 2013). Ich powstawanie dobrze wyjaśnia również koncepcja przełamywania 
progów rozwojowych zaproponowana przez Malisza (1966). To właśnie w sytuacji napotkania na określony próg rozwojowy (w tym przypadku próg technologiczny, wynikający z możliwości obsługi miasta z wykorzystaniem określonego środka transportu), a zatem i przestoju w rozwoju przestrzennym miasta, dochodzi do wytworzenia się na jego obrzeżach kolejnego pierścienia o ekstensywnym użytkowaniu.

Szczególnie wartościowa w kontekście rozpatrywanego w niniejszym opracowaniu zagadnienia rozrostu terytorialnego dużych miast wydaje się praca Mydla (1979), który przeanalizował zmiany gęstości zaludnienia i intensywności użytkowania terenu w powiązaniu z rozrostem terytorialnym Krakowa między XII w. a 1975 r. Mydel zaproponował dwa modele rozwoju miasta, tzn. model układów gęstości zaludnienia, który składa się z sześciu kolejnych faz (faza młodości, wczesna faza dojrzałości, faza dojrzałości, późna faza dojrzałości, faza starości i faza dyspersji) oraz model układów intensywności użytkowania ziemi, który składa się z dwóch stadiów (konwekcji i dyfuzji) i pięciu faz. Stadium konwekcji trwało od XIII do XIX w. i charakteryzowało się rozwojem miasta „ku górze” w obrębie murów obronnych (co związane było ze wzrostem intensywności użytkowania gruntów). W ramach tego stadium Mydel wyróżnił fazę inicjalną, wypełniania i nasycenia. Stadium dyfuzji rozpoczęło się od poszerzenia granic miasta i charakteryzowało się przestrzenną ekspansją użytków technicznych na wcielonych do miasta terenach. Stadium to dzieli się na: fazę koneksji (rozwój obszarów wcielonych do miasta związany był z silnymi związkami przestrzenno-funkcjonalnymi z jego strefą centralną i wzrostem intensywności użytkowania gruntów) i fazę katabatyczną (związaną z wysokim tempem procesów dyfuzji w strefie zewnętrznej i jednoczesnym obniżaniem stopnia intensywności użytkowania ziemi).

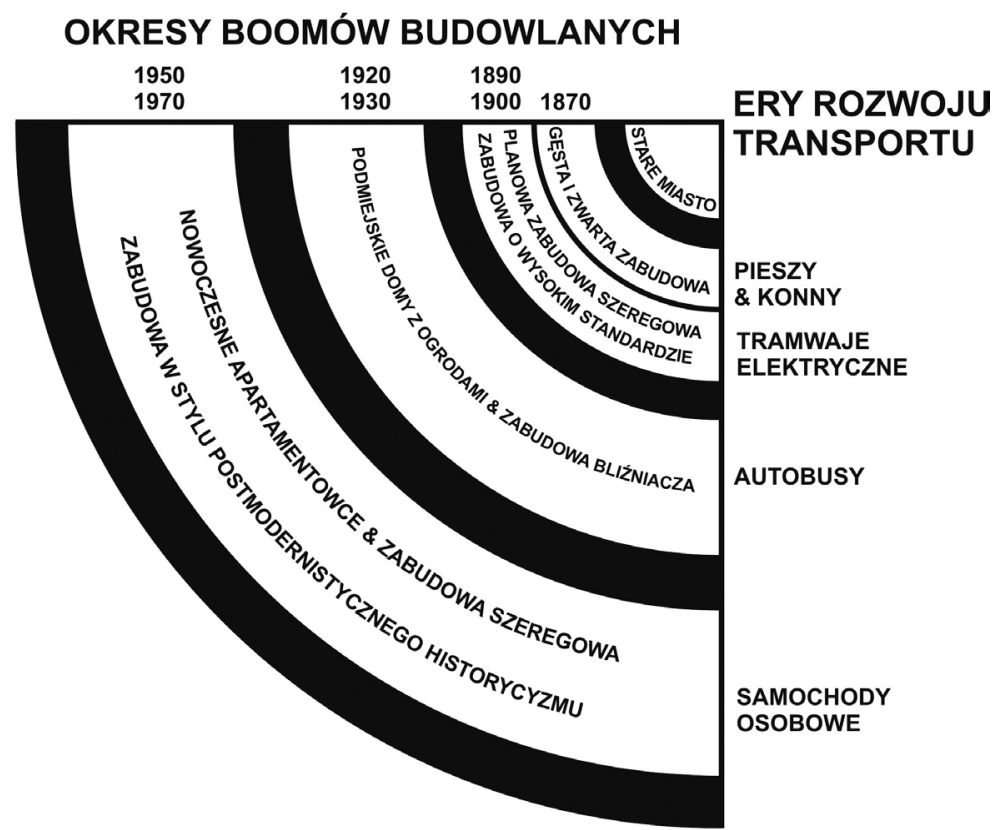

Ryc. 2. Historyczne strefy fringe belts, innowacje w transporcie i cykle budowlane wg Whitehanda (1988) Historic fringe belts, innovations in transport and building cycles after Whitehand (1988) Opracowanie własne na podstawie Whitehand (1988). 


\section{Metody badań i źródła danych}

Głównym celem opracowania była identyfikacja rozrostu terytorialnego dużych miast w Polsce na przykładzie Wrocławia, Krakowa i Warszawy, co wymagało zebrania informacji na temat zmian granic administracyjnych w tych miastach, począwszy od powstania (lokacji) miasta w XIII w. aż do czasów współczesnych. W celu przeanalizowania wpływu zmian administracyjnych na zmiany gęstości zaludnienia zebrano również informacje na temat liczby ludności w ich granicach administracyjnych. Podstawowym źródłem danych w tym zakresie są spisy ludności, a także dostępne bazy danych statystycznych. W przypadku Śląska (w tym również Wrocławia) pierwszy spis ludności miał miejsce w 1747 r., natomiast kolejne odbywały się w różnych odstępach czasu, średnio jednak co kilkanaście lat. Podobnie było również w przypadku pozostałych miast. Wcześniejsze dane ludnościowe to w większości przypadków szacunki opierające się na określonych przez różnych autorów założeniach, zazwyczaj określających statystyczną zależność między liczbą budynków mieszkalnych a potencjalną liczbą mieszkańców. Znacznie mniej problematyczne są z kolei dane dotyczące powierzchni analizowanych miast, gdyż od momentu swego powstania miasta te miały ściśle określone granice administracyjne. Jako problematyczny można uznać jedynie okres trwający od średniowiecza do momentu zburzenia murów obronnych, kiedy wokół miast funkcjonowały przedmieścia, ściśle powiązane funkcjonalnie z miastem, jednak pozostające faktycznie poza jurysdykcją miejską. Ich powierzchnia nie była wliczana w powierzchnię ogólną miasta, jednak wielu autorów zaliczało mieszkańców przedmieść do ogólnej liczby ludności miasta. Stąd też żeby określić faktyczną gęstość zaludnienia w obrębie murów miejskich populację miasta szacowano na podstawie stosunku liczby ludności miasta i przedmieść wykazanych w spisach ludności (np. w przypadku Wrocławia ludność miasta wg spisu z 1747 r. stanowiła 2/3 ludności całego zespołu miejskiego). W celu określenia związków (korelacji przestrzennej) pomiędzy rozrostem terytorialnym i faktycznym rozwojem przestrzennym obszarów zurbanizowanych, w tym zabudowy miejskiej, dokonano analizy dostępnych materiałów kartograficznych, w szczególności historycznych planów miast, a także map topograficznych dostępnych dla tych obszarów od poł. XIX w. Zbiór ten obejmuje w sumie kilkaset map i planów.

\section{Koncepcja cykliczności w rozwoju terytorialnym dużych miast}

Punktem wyjścia do rozważań nad koncepcją cykliczności w rozwoju terytorialnym dużych miast była analiza zmian granic administracyjnych Wrocławia (Maleczyński et al., 1956; Miszewska, 1996), która wykazała pewne prawidłowości. Podobną specyfikę rozwoju wykazano jednak również w badaniach rozrostu terytorialnego Krakowa (Mydel, 1979; Motak, 2012). Po pierwsze, można zauważyć, że zmiany granic administracyjnych miasta następują w sposób pulsacyjny, stopniowo, a kolejne zmiany administracyjne są przerywane okresami stabilności granic o różnej długości. Po drugie, poszerzenie granic miasta następuje zazwyczaj po okresie intensywnego rozwoju społeczno-gospodarczego miasta w jego dotychczasowych granicach i w strefie otaczającej, silnie powiązanej z miastem i przeobrażanej pod wpływem miasta. Okresy dłuższej stabilności granic w większości odpowiadają z kolei okresom stagnacji społeczno-gospodarczej miasta. Po trzecie, zmiana granic administracyjnych miasta następuje w momencie przekroczenia pewnego (zmien- 
nego w czasie) progu gęstości zaludnienia, wyznaczającego kres możliwości rozwojowych miasta w jego dotychczasowych granicach. Każde poszerzenie granic miasta przyczynia się do wzrostu powierzchni miasta i wzrostu jego liczby mieszkańców, a zarazem do znaczącego spadku gęstości zaludnienia w jego granicach (por. Mydel, 1979; Miszewska, 1996), co wynika z wcielania w granice miasta obszarów mniej (niż to miasto) zurbanizowanych, a zarazem dysponujących wolnymi (potencjalnymi) terenami pod dalszy rozwój przestrzenny miasta. Po czwarte, sekwencja procesów rozwojowych i ich swoista powtarzalność w czasie wskazują na cykliczność zdarzeń, a następujące cykle kończą kolejne poszerzenia granic administracyjnych miasta.

Cykl zmian granic administracyjnych miasta składa się z pięciu zasadniczych faz (ryc. 3). Faza I jest fazą inicjalną, która następuje w momencie powstania miasta (określenia jego granic), a w przypadku kolejnych cykli - poszerzenia granic miasta. W fazie II następuje wzrost liczby mieszkańców i gęstości zaludnienia w obrębie miasta, będący następstwem jego rozwoju społeczno-gospodarczego. W fazie III następuje dalszy wzrost gęstości zaludnienia w granicach miasta, a po przekroczeniu progu jego możliwości rozwojowych dochodzi do wylania miasta na jego najbliższe otoczenie. W fazie IV oddziaływanie miasta na jego otoczenie przyczynia się do dalszego rozwoju przedmieść (co wynika z ustabilizowania się sytuacji ludnościowej w granicach miasta). Proces ten może też często obejmować podmiejskie miejscowości (wsie lub mniejsze miasta) silnie powiązane z miastem. W fazie $V$ powiązanie funkcjonalne miasta z jego otoczeniem (suburbiami) jest na tyle duże, że następuje poszerzenie granic administracyjnych miasta o tereny podmiejskie, stanowiące naturalne przedłużenie miasta. Przyczynia się to do zwiększenia powierzchni i liczby ludności miasta, a zarazem do znaczącego spadku gęstości zaludnienia w jego nowych granicach. Faza ta stanowi jednocześnie fazę inicjalną dla kolejnego cyklu rozwoju przestrzennego i rozrostu terytorialnego miasta.

W przypadku Wrocławia można wyróżnić 7 pełnych cykli rozrostu terytorialnego (ryc. 4). Pierwszy cykl związany jest z rozwojem miasta średniowiecznego. Został on zainicjowany lokacją miasta w 1226 r. i powtórną lokacją w 1242 r. Dynamicznie rozwijające

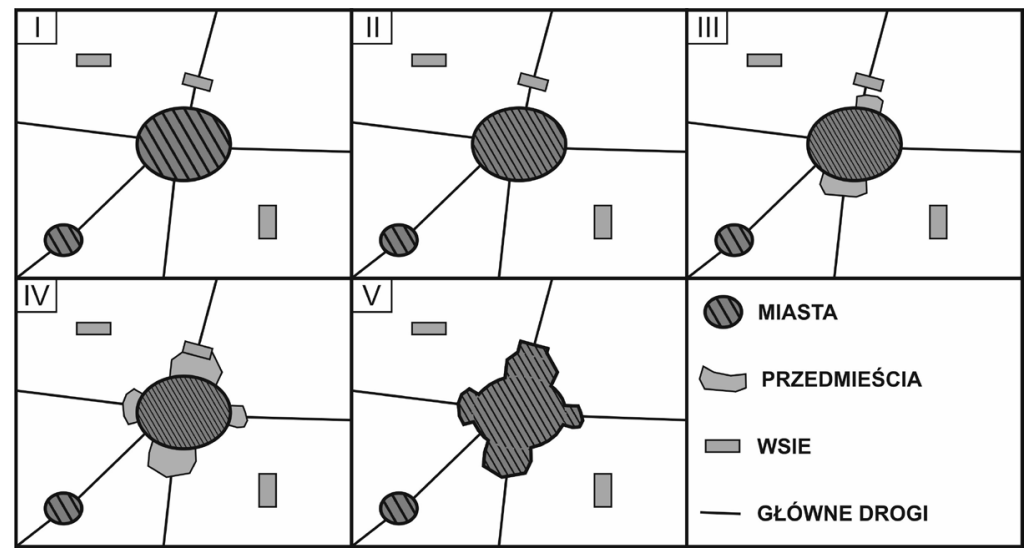

Ryc. 3. Model cyklicznego rozrostu terytorialnego dużych miast Opis poszczególnych faz w tekście A cyclical model of the territorial development of large cities Description of particular phases in the text 


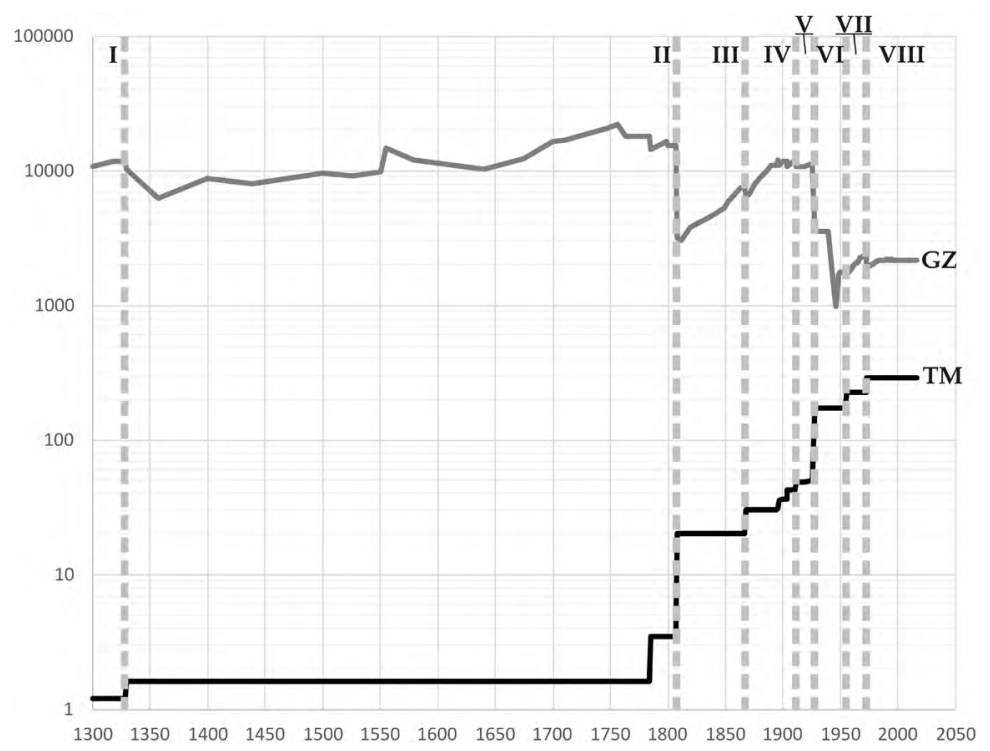

Ryc. 4. Cykle rozrostu terytorialnego Wrocławia

GZ - gęstość zaludnienia, TM - terytorium miasta

Cycles of territorial development in Wrocław

się miasto dość szybko przestało się mieścić w murach miejskich, stąd gwałtowny rozwój przedmieść wokół murów miejskich i lokacja tzw. drugiego miasta (Nowe Miasto), uzupełniającego dla miasta głównego. Cykl ten kończy się poszerzeniem granic Wrocławia o bliskie przedmieścia (1300 r.) i Nowe Miasto (1327 r.). W takich granicach miasto pozostało w zasadzie aż do końca XVIII w. Co prawda wokół murów miejskich powstawały liczne przedmieścia, jednak formalnie pozostawały ona poza jurysdykcją władz miejskich. W tym czasie liczba ludności Wrocławia stopniowo rosła, choć przyrost ten nie był zbyt znaczący, na co wpływ miały liczne klęski żywiołowe (powodzie, pożary), epidemie i działania wojenne (wojny husyckie w XV w. czy wojna trzydziestoletnia w latach 1618-1648, w wyniku której liczba ludności miasta zmniejszyła się o 10,0 tys. osób). Co więcej, rozwojowi miasta nie sprzyjała też niestabilna sytuacja polityczna (częste zmiany przynależności politycznej Śląska). Najważniejszą barierą rozwoju przestrzennego miasta był jednak mur miejski, który wyznaczał jego zasięg, a tym samym ograniczał jego rozwój do procesów zagęszczania. Stąd też wzrost liczby ludności w tym okresie następował głównie w obrębie murów miejskich (z 16,0 tys. w 1329 r. do 44,2 tys. w 1799 r.), powodując tym samym gwałtowny wzrost gęstości zaludnienia z 10,2 tys. osób na $\mathrm{km}^{2}$ do 27,1 tys. osób na $\mathrm{km}^{2}$ ), a w mniejszym stopniu także na przedmieściach bezpośrednio przylegających do murów miejskich. Przeludnione miasto potrzebowało wolnych przestrzeni pod dalszy rozwój. Umożliwiła to dopiero decyzja Napoleona Bonaparte o wyburzeniu murów miejskich (w 1807 r.), która przyczyniła się do poszerzenia granic administracyjnych miasta o obszar jego przedmieść.

Z rozwojem miasta dziewiętnastowiecznego związane są dwa, szybko następujące po sobie cykle kończące się poszerzeniem granic miasta w 1868 r. i w latach 1895-1911. W obu przypadkach scenariusz był podobny: gwałtowny wzrost liczby ludności generowany przez wysoki przyrost naturalny i napływ migrantów z terenów wiejskich powodował 
szybki wzrost gęstości zaludnienia w granicach miasta, inicjując tym samym intensywny ruch budowlany na terenach wcielanych do miasta. Stopniowy rozrost terytorialny miasta w XIX w. i na początku XX w. okazał się jednak niewystarczający, zwłaszcza w kontekście bardzo gwałtownego przyrostu liczby mieszkańców (z 335,2 tys. w 1890 r. do 526,2 tys. w 1911 r.). Miasto nadal borykało się z problemem przeludnienia, dużym zagęszczeniem zabudowy czy brakiem wolnych przestrzeni. Stąd też wokół Wrocławia zaczęły rozwijać się przedmieścia, głównie o charakterze eksurbiów dobrze powiązanych z miastem dzięki liniom kolejowym, ale także suburbiów bezpośrednio przylegających do miasta. Cykl ten kończy poszerzenie granic miasta w latach 1924-1928, w wyniku którego nastąpił ponad trzykrotny wzrost powierzchni miasta oraz znaczący spadek gęstości zaludnienia w jego granicach. Pozyskanie nowych terenów umożliwiło swobodny rozwój przestrzenny miasta. Na włączonych terenach koncentrował się ruch budowlany, co przyczyniło się do częściowego przeobrażenia morfologii dawnych wsi (Miszewska, 2002).

Dalszy rozwój przestrzenny miasta w jego nowych granicach wyhamowała II wojna światowa. Podczas oblężenia miasta w 1945 r. większość zabudowy w centrum i dzielnicach śródmiejskich została zniszczona. Umożliwiło to sanację bloków urbanistycznych w znacznym stopniu wypełnionych dotąd zabudową (Miszewska i Szmytkie, 2015). Okazało się również, że rozrost terytorialny miasta w okresie międzywojennym nie nawiązywał w pełni do faktycznych kierunków jego rozwoju przestrzennego. W granicach Wrocławia znalazły się bowiem słabo powiązane z miastem wsie, oddalone od jego centrum nawet o kilkanaście km, natomiast poza jego granicami silnie z nim powiązane i rozwijające się suburbia (ryc. 5). Zmiana granic miasta w 1951 r. miała na celu włączenie po-

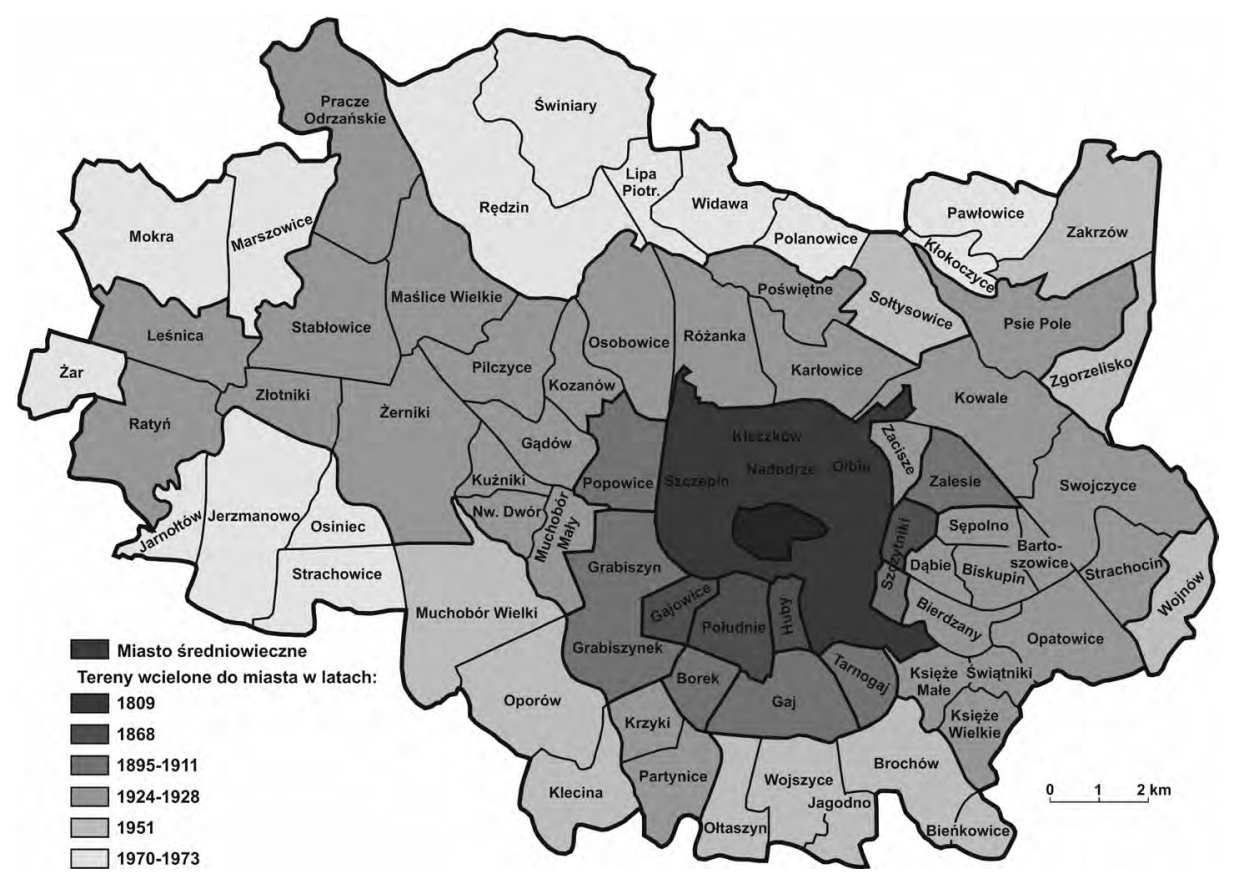

Ryc. 5. Rozrost terytorialny Wrocławia w latach 1807-2019

Territorial development of Wrocław, 1807-2019 
łudniowych, wschodnich i północnych przedmieść, stanowiących faktyczne przedłużenie miasta. Kolejny, siódmy cykl rozrostu terytorialnego Wrocławia, związany był z szybkim przyrostem liczby mieszkańców w okresie powojennym. Gęstość zaludnienia Wrocławia już w latach 70 XX w. osiągnęła poziom ok. 2,4 tys. osób na km², co w obliczu planowej urbanizacji i industrializacji kraju wprowadziło konieczność poszerzenia granic miasta w latach 1970-1973. Większość wcielonych do Wrocławia wsi stało się z czasem (zwykle 20-30 lat) integralnymi osiedlami miasta, jednak część z nich zachowała swój pierwotny charakter. W granicach miasta funkcjonuje obecnie kilkanaście osiedli o wiejskim charakterze (Szmytkie, 2011) i kilkanaście kolejnych, w których dawne wsie stały się centrami (jądrami genetycznymi) powojennych osiedli mieszkaniowych (Miszewska, 2002). Co więcej, od tego momentu gęstość zaludnienia w granicach miasta nie przekroczyła poziomu z lat 70., co związane było z wyhamowaniem rozwoju dużych miast w latach 80. XX w.

Poważne zmiany w zakresie rozwoju przestrzennego Wrocławia przyniosła dopiero transformacja społeczno-gospodarcza po 1989 r. Przejście od gospodarki centralnie sterowanej do gospodarki wolnorynkowej uruchomiło procesy suburbanizacji w otoczeniu dużych miast w całym regionie Europy Środkowo-Wschodniej (Sýkora i Ouředníček, 2007; Brade et al., 2009; Hirt i Stanilov, 2009; Kubeš, 2013). W przypadku Wrocławia w ostatnich latach nastąpił gwałtowny rozwój zabudowy w strefie podmiejskiej oraz w peryferyjnych dzielnicach miasta (tzw. wewnętrzna suburbanizacja), a także wzrost powiązań między miastem a jego bliskim otoczeniem (Brezdeń i Szmytkie, 2019) (ryc. 6). Pytaniem otwartym jest to czy (a w zasadzie kiedy) ten cykl rozwoju przestrzennego Wrocławia zakończy się poszerzeniem jego granic administracyjnych.

Podobne procesy mają również miejsce w innych dużych miastach w Polsce i całej Europie Środkowo-Wschodniej. Cykliczność w zakresie rozrostu terytorialnego uwidacznia się np. w przypadku Krakowa i Warszawy. Dla Krakowa można wyodrębnić 6 pełnych

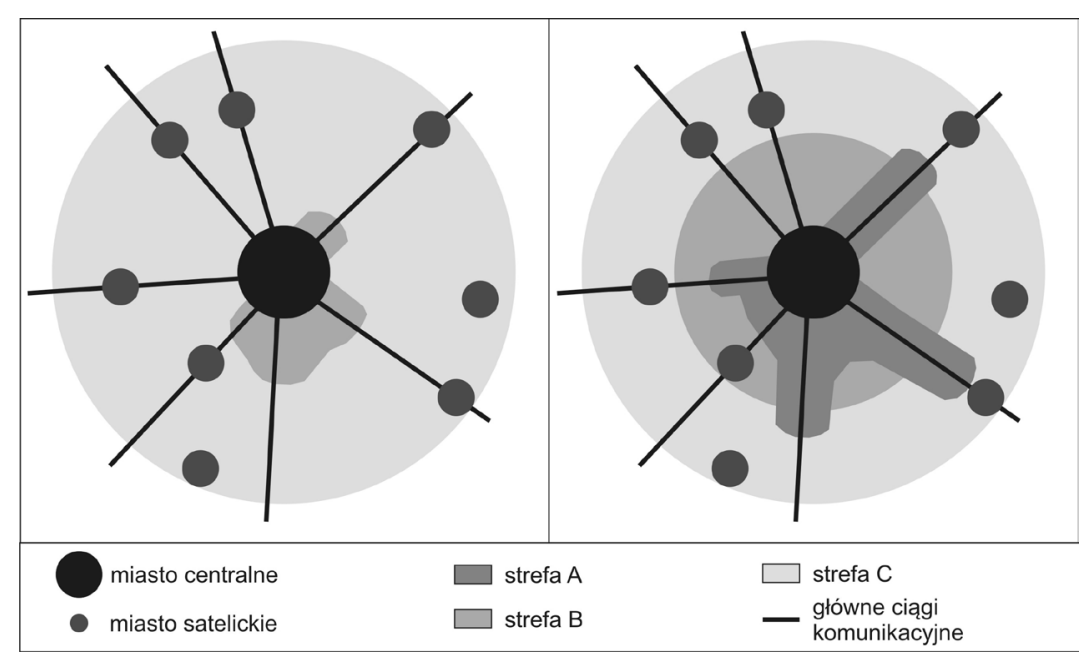

Ryc. 6. Model koncentracji działalności przemysłowej w strefie podmiejskiej Wrocławia (Brezdeń i Szmytkie, 2019) strefa A - strefa o funkcji mieszkaniowo-przemysłowej, strefa B - strefa o funkcji mieszkaniowej i mieszkaniowo-rolniczej, strefa C - strefa o funkcji rolniczej i rolniczo-mieszkaniowej

Model of the concentration of industrial activity in Wrocław's suburban zone (Brezdeń and Szmytkie, 2019) Opracowanie własne na podstawie Brezdeń i Szmytkie (2019). 
cykli rozwojowych (ryc. 7). Co więcej, zmiany granic administracyjnych miasta przypadają na inne lata niż ma to miejsce w przypadku Wrocławia (1450, 1792-1800, 1900-1915, 1941, 1951, 1973-1986) (Mydel, 1979), co związane m.in. jest z odmiennością losów historycznych Śląska i Małopolski. Gwałtowny rozwój miasta średniowiecznego spowodował wcielenie w granice Krakowa wzgórza Wawel i miasta Okół w 1450 r. Po okresie świetności, niekorzystne warunki ekonomiczne i społeczno-polityczne w XVII i XVIII w. (przeniesienie stolicy do Warszawy w 1609 r., wojny szwedzkie, pierwszy rozbiór Polski) przyczyniły się do upadku Krakowa. Pierwsze oznaki ożywienia gospodarczego pojawiły się u schyłku Rzeczypospolitej. Na przeszkodzie rozwoju przestrzennego Krakowa stanęły jednak jurydyki, które rozwinęły się w sąsiedztwie miasta w pierwszej połowie XVIII w. Likwidacja samorządu jurydyk w 1791 r. przyczyniła się do scalenia miasta i przedmieść w 1792 r. (Mydel, 1979).

Zauważalny jest także wolniejszy rozwój Krakowa w dobie przemysłowej (XIX w.), skutkiem czego w tym okresie miał miejsce tylko jeden (a nie dwa jak we Wrocławiu) pełny cykl rozrostu terytorialnego miasta. Związane to było z zajęciem miasta przez Austrię w $1846 \mathrm{r}$. i przekształceniem go w twierdzę. W tej sytuacji rozwój miasta w II połowie XIX w. następował na obszarach przyłączonych do Krakowa w 1792 r. Przyczyniło się to do znaczącego wzrostu gęstości zaludnienia w jego granicach (do 12,4 tys. na km²) i gwałtownego rozwoju przedmieść, a następnie poszerzenia terytorium miasta. W latach 1910-1915 do Krakowa przyłączono 12 gmin wiejskich i miasto Podgórze. W okresie międzywojennym Kraków, jako ośrodek wojewódzki, miał korzystne warunki dla ogólnego rozwoju społeczno-gospodarczego. Dynamicznemu procesowi przemian miasta towarzyszyło znaczne ożywienie gospodarcze gmin podmiejskich, przejawiające się intensywnym ruchem budowlanym na ich terenie. W obawie o swobodny rozwój przestrzenny miasta zdecydowano o poszerzeniu granic Krakowa w 1941 r. Dalszy rozwój miasta po II wojnie światowej prowadzo-

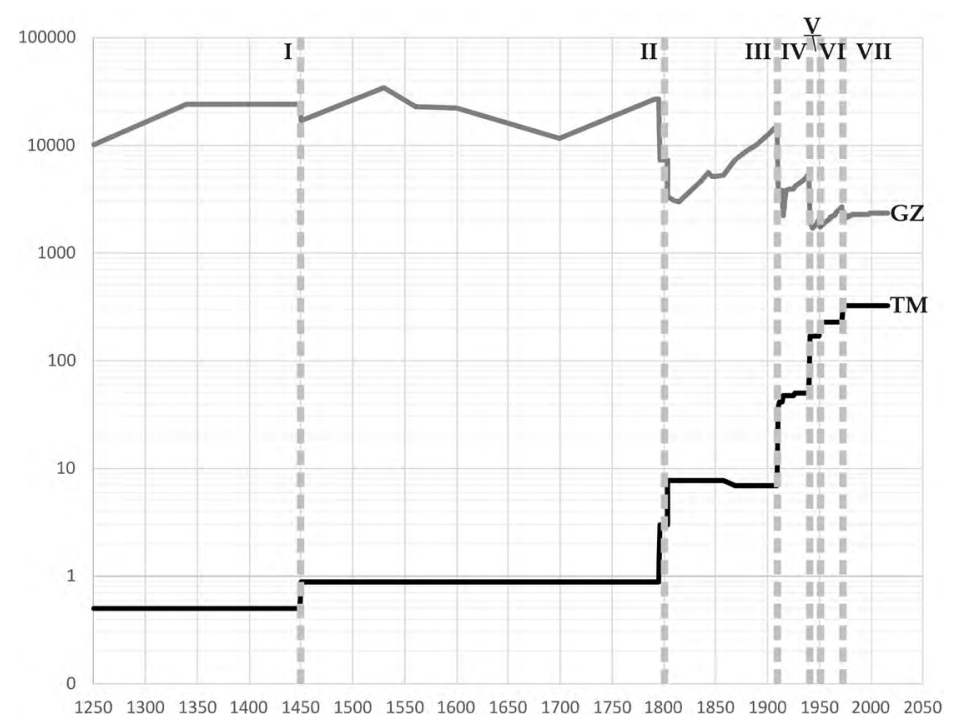

Ryc. 7. Cykle rozrostu terytorialnego Krakowa

GZ - gęstość zaludnienia, TM - terytorium miasta

Cycles of territorial development in Cracow 
ny był w ramach planowej działalności urbanistycznej, kształtującej Kraków jako ośrodek przemysłowy. W 1949 r. na północny-wschód od miasta powstał kombinat hutniczy (Nowa Huta), który wraz z 12 wsiami objętymi działalnością inwestycyjną został w 1951 r. wcielony do miasta. Kolejne poszerzenia jego granic miały miejsce w latach 70. i 80. XX w., co związane było z chęcią zapewnienia właściwego zagospodarowania obszarów przyległych, stanowiących jednocześnie rezerwę terenów dla rozwijającego się Krakowa (Mydel, 1979). Obecnie, podobnie jak w przypadku Wrocławia, rozwój zabudowy w granicach miasta umożliwia znaczny udział użytków rolnych (47\%), stąd intensywny rozwój budownictwa mieszkaniowego w peryferyjnych osiedlach (w strefie wewnętrznych suburbiów).

Inaczej przedstawia się rozwój przestrzenny Warszawy, która znacznie później niż Wrocław i Kraków stała się ośrodkiem regionalnym (dopiero w XV w.) i jej intensywny rozwój nastąpił dopiero po przeniesieniu stolicy Polski z Krakowa (II poł. XVI w.). Początkowo miasto w obrębie murów miejskich zajmowało 12 ha. Stały rozwój miasta spowodował powstanie w XIV i XV w. zabudowy na przedmieściach (Freta na północy, Przedmieście Czerskie na południu, przedmieście Długa na zachodzie) oraz odrębnego miasta Nowa Warszawa. Przedmieścia te włączono w granice miasta w 1579 r. Od końca XVI w. rozwój Warszawy przebiegał znacznie bardziej dynamicznie niż w pozostałych miastach, stąd większa liczba pełnych cykli rozrostu terytorialnego (8), a kończące je zmiany granic miasta przypadały na lata: 1579, 1655, 1786, 1831, 1908-1916, 1925-1938, 1951-1957, 1977, 1992-2002 (ryc. 8) (por. Wilski, 1993; Bartoszewicz, 2003; Królikowski i Ostrowski, 2009). W 1624 r. zasięg przestrzenny miasta, wyznaczał tzw. Wał Zygmuntowski, w granicach którego miasto liczyło 125 ha. Pierwsza połowa XVIII w. była okresem dalszego intensywnego rozwoju, co przyczyniło się do urbanizacji terenów na prawym brzegu Wisły (w $1641 \mathrm{r}$. prawa miejskie otrzymał Skaryszew, a w 1648 r. Praga). Na przedmieściach lewobrzeżnych zabudowa wyszła poza obręb wałów, głównie w kierunku południowym i zachod-

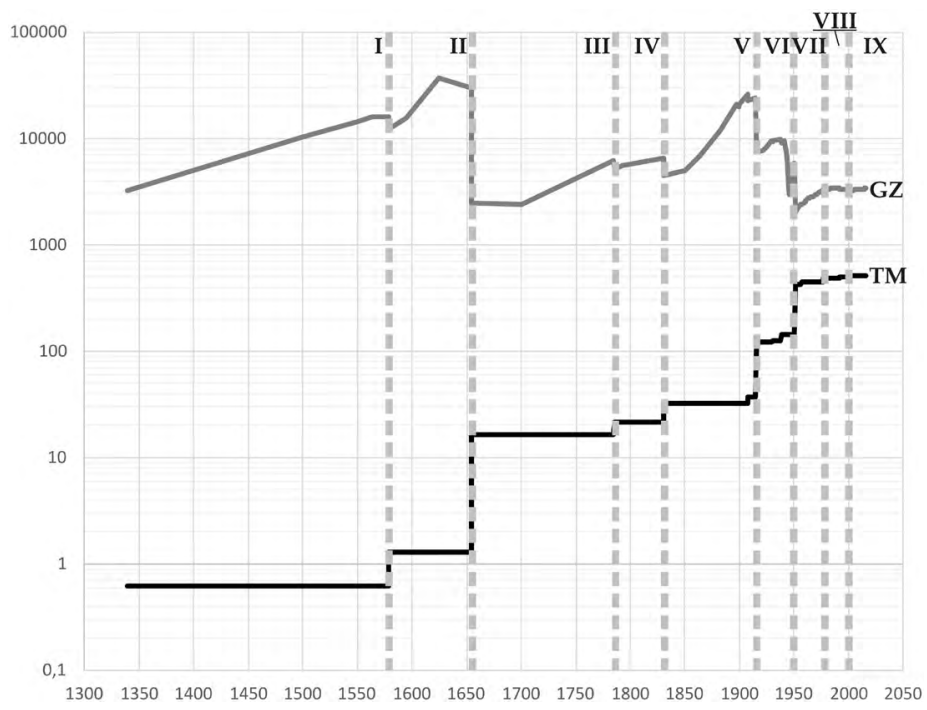

Ryc. 8. Cykle rozrostu terytorialnego Warszawy

$\mathrm{GZ}$ - gęstość zaludnienia, TM - terytorium miasta

Cycles of territorial development in Warsaw 
nim. Powstały w tym czasie pierwsze jurydyki (m.in. Leszno, Grzybów i Bielino). Podczas wojen polsko-szwedzkich miasto w znacznym stopniu zostało zniszczone. Nie zahamowało to jednak jego dalszego rozwoju przestrzennego. Wokół miasta powstawały nowe jurydyki, głównie na gruntach folwarku Starościńskiego i na dawnych rolach miejskich, a na zurbanizowanych terenach zaczęły powstawać założenia urbanistyczne (m.in. Oś Saska, Kalwaria Ujazdowska, place gwiaździste w okresie stanisławowskim).

Obszary przedmieść wcielone pod koniec XVIII w. zostały otoczone kolejnym wałem ziemnym (tzw. Wał Lubomirskiego). Doszło też do formalnego połączenia w jeden organizm miejski Starej i Nowej Warszawy. Powstała po upadku powstania styczniowego Cytadela stała się barierą w rozwoju przestrzennym miasta w kierunku północnym. Otoczenie lewobrzeżnej części miasta pierścieniem fortów przyczyniło się do powstawania przedmieść o bezplanowej, substandardowej zabudowie. Rozwój sieci kolejowej w II połowie XIX w. przyczynił się z kolei do rozbudowy przedmieść o charakterze przemysłowym (m.in. Nowa Praga, Targówek), które wcielono do miasta na przełomie XIX i XX w. Ruch budowlany w tym czasie koncentrował się wewnątrz miasta, co przyczyniło się do maksymalnego wykorzystania terenu oraz spekulacji gruntami. Sytuacja ta niejako wymusiła znaczące poszerzenie granic miasta w 1916 r. i kolejne w latach 1925-1938. Na włączonych do miasta terenach postępowała intensyfikacja zabudowy. Podczas II wojny światowej zabudowa Warszawy została zniszczona w 85\%. Zniszczenia dotyczyły zwłaszcza lewobrzeżnej części miasta. Po wyzwoleniu opracowano kilka wersji planu odbudowy i przebudowy stolicy. W ramach tych projektów obszar miasta powiększono w latach 1951-1957 do 430 km², przyłączając do Warszawy ok. 80 miejscowości. Intensywny rozwój miasta w okresie powojennym przyczynił się do kolejnych poszerzeń jego granic administracyjnych w latach 70. i 90. XX w. Co więcej, obecnie Warszawa zbliża się obecnie do kolejnego progu gęstości zaludnienia (wg danych GUS gęstość zaludnienia w mieście wynosi 3,4 tys. osób na km², jednak faktycznie wartość ta może dochodzić nawet do 4,5-5,0 tys. osób na km²) i zaczyna powoli brakować wolnych przestrzeni pod dalszą zabudowę (udział użytków rolnych sięga 23\%, z kolei udział gruntów zabudowanych i zurbanizowanych 56\% - przy ok. 44\% w przypadku Wrocławia i Krakowa). Stąd też pojawiające się w ostatnich latach pomysły na kolejne poszerzenie granic administracyjnych miasta (Śleszyński, 2018).

\section{Dyskusja}

W artykule skupiono się głównie na czynnikach budujących i niszczących w rozwoju przestrzennym miast, a także na uwarunkowaniach ekonomicznych, społecznych, technologicznych i politycznych tych procesów. Wykazano, że rozrost terytorialny miasta jest następstwem okresu rozwoju społeczno-gospodarczego, z kolei dłuższe okresy stabilności granic administracyjnych przypadają na okresy stagnacji lub oddziaływania niekorzystnych czynników (jak np. działania wojenne, klęski żywiołowe, niestabilna sytuacja polityczna, okresy zastoju gospodarczego), na co wskazują również badania Lawtona (1973), koncepcja cykli budowlanych (Barras, 2009) czy koncepcja fringe belts (Whitehand, 1988). Istotną rolę w rozwoju przestrzennym dużych miast odegrał także transport (i związana z nim dostępność), który kształtował zasięg przestrzenny miasta, a zatem stanowił próg rozwojowy na danym etapie jego funkcjonowania (por. Malisz, 1966). Wpływ postępu technologicznego w transporcie na rozwój przestrzenny miast obrazuje model rozwoju fringe belts zapropo- 
nowany przez Whitehanda (1994). Co więcej, zaproponowane w modelu okresy przyrostu pierścieni obrzeży miejskich (ryc. 2) dobrze korespondują z okresami intensywnego rozwoju zabudowy i procesami zmian granic administracyjnych, które kończą poszczególne cykle rozrostu terytorialnego Wrocławia (ryc. 4), Krakowa (ryc. 7) czy też Warszawy (ryc. 8). W przypadku Wrocławia trudno jednak, z wyjątkiem Promenady Staromiejskiej (powstałej w miejscu dawnych murów miejskich) i fosy miejskiej, wyróżnić kolejne pierścienie klasycznych fringe belts, co może świadczyć o bardzo szybkim rozwoju przestrzennym miasta w XIX i XX w. W przypadku Krakowa ich funkcję pełnią z kolei Planty, otaczające Stare Miasto.

Intensywność rozwoju przestrzennego miast wzrosła w XIX w., a motorem napędowym tego procesu stał się przemysł. Jak wykazał Lawton (1972) rozwój ten początkowo przebiegał koncentrycznie, co widoczne jest także w przypadku Wrocławia i Krakowa. Wraz z rozwojem transportu pod koniec XIX w. charakter rozwoju przestrzennego miast zmienił charakter na klinowy, gdyż duże miasta zaczęły rozwijać się wzdłuż głównych szlaków komunikacyjnych, a zwłaszcza w kierunku leżących w ich sąsiedztwie mniejszych miast. W przypadku Wrocławia czynnikiem zaburzającym koncentryczność rozrostu terytorialnego miasta były miasteczka: Leśnica (leżąca 12 km na zachód) i Psie Pole (leżące 7,5 km na północny-wschód od centrum miasta), natomiast w przypadku Krakowa - Nowa Huta. Według Krzysztofika (2014) wynika to z zassania przez większe miasto części potencjału mniejszego miasta. Ten trend dobrze też obrazuje poszerzenie granic administracyjnych Wrocławia w 1928 r., które przyczyniło się do rozciągnięcia terytorium miasta w obu tych kierunkach. Ponadto, w trakcie kolejnych zmian granic administracyjnych miasta w XX w. w jego obręb wcielano obszary wiejskie leżące na obszarach nie podlegających intensywnym procesom urbanizacji, których rozwój w dalszym ciągu przebiegał w sposób koncentryczny, co związane jest z dostępnością komunikacyjną do centrum miasta (Brezdeń i Szmytkie, 2019).

Wykazano też, że wzrost gęstości zaludnienia w granicach miasta pociąga za sobą wzrost udziału terenów zurbanizowanych (przez zagęszczanie lub rozwój pionowy zabudowy). W tym aspekcie można się doszukiwać powiązań między fazami cyklu rozrostu terytorialnego miasta a fazami cyklu działki miejskiej zaproponowanymi przez Conzena (1960). Związek ten może uwidaczniać się w dwóch płaszczyznach. Po pierwsze wylanie się miasta na obszar podmiejski następuje po osiągnięciu określonego poziomu gęstości zaludnienia, który można utożsamiać z fazą climaxu, czyli maksymalnego wypełnienia działki (bloku urbanistycznego). Po drugie na obszarach wcielanych do miasta następuje sekwencja zjawisk według schematu zaproponowanego przez Conzena, przy czym ich dynamika jest znaczna, przez co przejście od fazy inicjalnej do fazy climaxu może nastąpić nawet w ciągu kilkudziesięciu lat. Przykład Wrocławia i Warszawy pokazuje również, że sanacja bloku urbanistycznego może przebiegać poprzez rozgęszczenie zabudowy bądź też całkowity lub częściowy jej ubytek (np. w wyniku zniszczeń wojennych).

Analizując zmiany granic administracyjnych Wrocławia, Krakowa i Warszawy w XX w. można też stwierdzić, że rozrost terytorialny nie zawsze należy utożsamiać z faktycznym rozwojem przestrzennym miasta. Co więcej, można zauważyć, że nie każda zmiana granic administracyjnych miasta następuje po okresie jego intensywnego rozwoju społeczno-gospodarczego, o czym świadczy znaczący formalny rozrost powierzchni administracyjnej dużych miast w Polsce w latach 50. XX w. (Szmytkie, 2019), często silnie zniszczonych w wyniku działań wojennych (por. Musiaka et al. 2020), który wyprzedził na dziesięciolecia ich rzeczywisty rozwój przestrzenny. W tym czasie w granicach analizowanych miast znalazły się bowiem słabo z nimi powiązane wsie, a poziom zaawansowania procesów urbanizacji 
na ich terenie jest na tyle niski, że można stwierdzić, że miejscowości te w wielu przypadkach zachowały swój pierwotny charakter (por. Szmytkie, 2011). Jest to zjawisko typowe dla wielu miast post-socjalistycznych, które w ramach planowej urbanizacji kraju często były powiększane „na wyrost” (tendencja do tworzenia dużych form), co wpłynęło na ich struktury przestrzenne (Andrusz, 1996; Sýkora, 1999; Crowley i Reid, 2002; Hirt, 2013). Paradoksalnie taki rozrost terytorialny miasta umożliwia obecnie rozwój wewnętrznych suburbiów (przeciwdziałając tym samym niekorzystnej z punktu widzenia miasta właściwej suburbanizacji) (Sýkora, 1999; Tosics, 2006; Stanilov, 2007; Sýkora i Ouředníček, 2007; Nagy i Timár, 2012; Kubeš, 2013), gdyż nowa zabudowa mieszkaniowa powstaje głównie na terenach użytków rolnych, które w przypadku wielu miast stanowią znaczny udział ich powierzchni. Można więc stwierdzić, że zbyt szerokie określenie granic miasta w okresie socjalizmu przyczyniło się do wyhamowania jego rozrostu terytorialnego po 1989 r.

W tym miejscu warto również zwrócić uwagę na kwestię miast-zlepieńców, które dość powszechnie tworzone były w krajach Europy Środkowo-Wschodniej, zwłaszcza w obszarach uprzemysłowionych (Szmytkie, 2009; Szmytkie i Krzysztofik, 2019). Ich rozrost terytorialny następował bardzo dynamicznie, wskutek odgórnych decyzji administracyjnych, zwykle bez związku z ich rzeczywistym rozwojem przestrzennym. Powstające w ich wyniku „miasta”, składały się de facto z luźno powiązanych ze sobą osiedli, co w wielu przypadkach prowadziło do ich szybkiego, częściowego lub całkowitego rozpadu. Należy także nadmienić, że rozwój przedmieść jest nieodłącznym czynnikiem rozwoju przestrzennego miast (por. Harris i Larkham, 1999; Brueckner, 2000). Co więcej, nie jest to zjawisko nowe, które zostało zapoczątkowane w dobie przemysłowej, pod koniec XIX w. Podobne procesy rozwoju przedmieść obserwowane były bowiem już znacznie wcześniej, bo jak inaczej można zaklasyfikować procesy rozwoju miast średniowiecznych? Zjawisko to dotyczy jednak określonej grupy miast - monocentrycznycyh ośrodków regionalnych rozwijających się w wyniku oddziaływania sił dośrodkowych w ujęciu fizykalistyczno-funkcjonalnym (siły równoważące rozwój miasta i jego zaplecza) (Krzysztofik, 2014, 2016) (ryc. 9). Ich pozy-

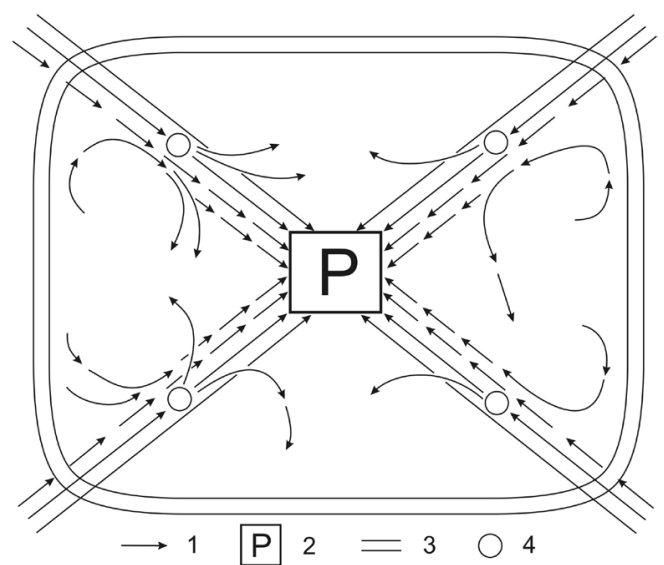

Ryc. 9. Działanie dośrodkowych sił miastotwórczych w podukładzie osadniczym

1 - kierunki działania sił miastotwórczych w podukładzie, 2 - punkt miastotwórczy, 3-granica podukładu, 4 - wtórne ośrodki podukładu, biorące udział w interakcjach warunkowanych działaniem sił miastotwórczych. Action of city-forming centripetal forces in the settlement subsystem Opracowanie własne na podstawie Krzysztofik (2014, s. 132). 
cja w regionie w większości przypadków została ukształtowana w okresie średniowiecza, co umożliwiło im na długotrwały rozwój oraz zbudowanie silnej, a zarazem zróżnicowanej funkcjonalnie bazy ekonomicznej. Znacznie krócej, jednak bardziej dynamicznie przebiegał rozwój (a obecnie kurczenie się) miast doby przemysłowej. W ich przypadku również można doszukać się znamion cykliczności w rozwoju przestrzennym, jednak poszczególne cykle są znacznie skrócone w czasie. Ponadto, przemysł stymuluje rozwój form policentrycznych (Krugman, 1997; Anas et al., 1998; Krzysztofik et al., 2016), a zatem powszechne jest zjawisko nakładania się podobnych procesów w przypadku blisko położonych ośrodków.

\section{Podsumowanie}

Analiza zmian granic administracyjnych, gęstości zaludnienia oraz kierunków rozwoju przestrzennego na przykładzie Wrocławia, Krakowa i Warszawy wykazała występowanie pewnej specyfiki rozrostu terytorialnego dużych miast w Polsce i podobieństwo procesów osadniczych w różnych okresach historycznych. Pozwoliło to na identyfikację określonych prawidłowości rozwoju, które z uwagi na ich powtarzalność, wskazują na cykliczny charakter procesów rozwojowych. Specyfikę rozrostu terytorialnego dużych miast można wyrazić w następujący sposób: każdy okres rozwoju społeczno-gospodarczego miasta przyczynia się do wzrostu gęstości zaludnienia w jego granicach, a następnie do wylania się miasta na obszar najbliższego otoczenia (jego strefy podmiejskiej). Obszar ten stanowi faktycznie przedłużenie miasta i z czasem zostaje wcielony w jego granice administracyjne. Poszerzenie granic miasta powoduje zwykle spadek gęstości zaludnienia w jego nowych granicach. Każdy kolejny okres prosperity miasta inicjuje kolejny cykl rozrostu terytorialnego. Niestabilna sytuacja społeczno-ekonomiczna miasta ogranicza rozwój przestrzenny miasta i pokrywa się z dłuższymi okresami stabilności jego granic administracyjnych. Opisana powyżej cykliczność w zakresie rozrostu terytorialnego dotyczy określonej grupy miast - monocentrycznych ośrodków regionalnych rozwijających się w wyniku oddziaływania sił dośrodkowych w ujęciu fizykalistyczno-funkcjonalnym. Przeprowadzone w pracy badania wykazały również, że rozwój terytorialny miasta nie zawsze nawiązuje do faktycznych kierunków rozwoju przestrzennego. W XX w. typowym zjawiskiem w przypadku dużych miast w Polsce i innych krajach Europy Środkowo-Wschodniej było znaczące powiększanie ich granic administracyjnych, typowe dla gospodarki centralnie sterowanej, nastawionej na planową urbanizację i industrializację. Obecnie miasta położone w tym regionie wkroczyły w fazę intensywnej suburbanizacji, która przyczynia się do znaczącego rozwoju obszarów zurbanizowanych, zwłaszcza w otoczeniu dużych miast.

Ryciny, pod którymi nie zamieszczono źródła, są opracowaniami własnymi autora artykułu. 


\section{Piśmiennictwo}

Anas, A., Arnott, R., \& Small, K.A. (1998). Urban Spatial Structure. Journal of Economic Literature, 36(3), 1426-1464.

Andrusz, G. (1996). Structural change and boundary instability. W: G. Andrusz, M. Harloe, \& I. Szelenyi (red.), Cities after socialism: Urban and regional change and conflict in post-socialist societies (s. 30-69). Malden: Blackwell.

Arnott, R.J. (1980). A simple urban growth model with durable housing. Regional Science and Urban Economics, 10(1), 53-76. https://doi.org/10.1016/0166-0462(80)90048-4

Baranowska, M. (2007). Koncepcja zjawiska fringe belt. W: I. Jażdżewska (red.), Polska geografia osadnictwa, dotychczasowy dorobek, program badań. XX Konwersatorium wiedzy o mieście (s. 177-183). Łódź: Wydawnictwo Uniwersytetu Łódzkiego.

Barke, M. (1976). Land use succession: a factor in fringe-belt modification. Area, 8(4), 303-306. https://doi.org/10.2307/212588

Barras, R. (2009). Building cycles: growth and instability. John Wiley \& Sons.

Bartoszewicz, H. (2003). Rozwój przestrzenny Warszawy w latach 1800-1914 w świetle źródet kartograficznych. Warszawa: Mazowiecka Wyższa Szkoła Humanistyczno-Pedagogiczna.

Borsdorf, A., Hidalgo, R., \& Sánchez, R. (2007). A new model of urban development in Latin America: The gated communities and fenced cities in the metropolitan areas of Santiago de Chile and Valparaíso. Cities, 24(5), 365-378. https://doi.org/10.1016/j.cities.2007.04.002

Brade, I., Herfert, G., \& Wiest, K. (2009). Recent trends and future prospects of socio-spatial differentiation in urban regions of Central and Eastern Europe: A lull before the storm? Cities, 26(5), 233-244. https://doi.org/10.1016/j.cities.2009.05.001

Brezdeń, P., \& Szmytkie, R. (2019). Current changes in the location of industry in the suburban zone of a post-socialist city. Case study of Wrocław (Poland). Tijdschrift voor Economische en Sociale Geografie, 110(2), 102-122. https://doi.org/10.1111/tesg.12339

Brueckner, J.K. (2000). Urban sprawl: diagnosis and remedies. International Regional Science Review, 23(2), 160-171. https://doi.org/10.1177/016001700761012710

Burgess, E.W. (1924). The growth of the city: an introduction to a research project. Publications of the American Sociological Society, 18, 85-97.

Carter, H., \& Wheatley, S. (1979). Fixation lines and fringe belts, land uses and social areas: nineteenth-century change in the small town. Transactions of the Institute of British Geographers, 4(2), 214-238. https://doi.org/10.2307/622036

Clark, C. (1951). Urban Population Densities. Journal of the Royal Statistical Society. Series A (General), 114(4), 490-496. https://doi.org/10.2307/2981088

Conzen, M.R.G. (1960). Alnwick, Northumberland: a study in town-plan analysis. Transactions and Papers of Institute of British Geographers, 27. https://doi.org/10.2307/621094

Crowley, D., \& Reid, S.E. (red.). (2002). Socialist spaces: Sites of everyday life in the Eastern Bloc. Oxford: Berg.

Daniel, P., \& Hopkinson, M. (1989). The Geography of Settlement. Conceptual Frameworks in Geography. Edinburg: Oliver \& Boyd.

Ducom, E. (2003). Fringe belts and planning: a French example. Urban Morphology, 7(2), 103-104.

Elkins, T.H., \& Hofmeister, B. (1988). Berlin: The spatial structure of a divided city. New York: Meuthen.

Enyedi, G., \& Szirmai, V. (1992). Budapest. A Central European Capital. London: Belhaven Press. 
Escher, F. (1985). Berlin und sein Umland. Zur Genese der Berliner Stadtlandschaft bis zum Beginn des 20. Jahrhunderts. Berlin: Colloquium Verlag.

Grzeszczak, J. (1996). Tendencje kontrurbanizacyjne w krajach Europy Zachodniej. Prace Geograficzne, 167, Warszawa: Instytut Geografii i Przestrzennego Zagospodarowania PAN.

Haggett, P. (1972). Geography: a modern synthesis. New York: Harper \& Row.

Hall, P. (1971). Spatial structure of metropolitan England and Wales. W: M. Chisholm, \& G. Manners (red.), Spatial policy problems of the British economy (s. 96-125). Cambridge: Cambridge University Press

Hall, P.G. (1998). Cities in civilization. New York: First Fromm International.

Hall, T., \& Barrett, H. (2012). Urban geography. London: Routledge.

Harris, C.D., \& Ullman, E.L. (1945). The Nature of Cities. The Annals of the American Academy of Political and Social Science, 242, 7-17. https://doi.org/10.1177/000271624524200103

Harris, R., \& Larkham, P.J. (1999). Changing suburbs: Foundation, Form and Function. London: Stage.

Hirt, S. (2013). Whatever happened to the (post) socialist city? Cities, 32, 29-38. https://doi.org/10.1016/j.cities.2013.04.010

Hirt, S., \& Stanilov, K. (2009). Twenty years of transition: The evolution of urban planning in Eastern Europe and the former Soviet Union, 1989-2009. Nairobi: Human Settlements Global Dialogue Series.

Horwood, E.M., \& Boyce, R.R. (1959). Studies of the central business district and urban freeway development. Seattle: University of Washington Press.

Hoyt, H. (1939). The Structure and Growth of Residential Neighborhoods in American Cities. Washington: Federal Housing Administration.

Isard, W. (1942). A neglected cycle: the transport-building cycle. Review of Economic Statistics, 24(4), 149-158. https://doi.org/10.2307/1927670

Klaassen, L.H., \& Paelinck, J.H.P. (1979). The future of large towns. Environment and Planning A, 11(10), 1095-1104. https://doi.org/10.1068/a111095

Korcelli, P. (1969). Rozwój struktury przestrzennej obszarów metropolitalnych Kalifornii. Prace Geograficzne, 78. Warszawa: IG PAN.

Królikowski, L., \& Ostrowski, M. (2009). Rozwój przestrzenny Warszawy. Warszawa: Mazowieckie Centrum Kultury i Sztuki.

Krugman, P.R. (1997). Development, Geography and Economic Theory. Cambridge, London: The MIT Press.

Krzysztofik, R. (2014). Geneza aglomeracji miast na obszarze Polski. Katowice: Wydawnictwo Uniwersytetu Śląskiego.

Krzysztofik, R., Tkocz, M., Spórna, T., \& Kantor-Pietraga, I. (2016). Some dilemmas of post-industrialism in a region of traditional industry: The case of the Katowice conurbation, Poland. Moravian Geographical Reports, 24(1), 42-54. https://doi.org/10.1515/mgr-2016-0004

Kubeš, J. (2013). European post-socialist cities and their near hinterland in intra-urban geography literature. Bulletin of Geography. Socio-economic Series, 19, 19-43. https://doi.org/10.2478/bog-2013-0002

Lawton, R. (1972). An age of great cities. Town Planning Review, 43(3), 199-224.

de Long, J.B., \& Shleifer, A. (1993). Princes and merchants: European city growth before the industrial revolution. The Journal of Law and Economics, 36(2), 671-702. https://doi.org/10.1086/467294

Louis, H. (1936). Die geographische Gliederung von Gross-Berlin. W: H. Louis, \& W. Panzer (red.), Landerkundliche Forschung: Krebs-Festschrift (s. 146-171). Stuttgart: Engelhorn.

Mann, P.H. (1965). An Approach to Urban Sociology. London: Routledge.

Malisz, B. (1966). Zarys teorii kształtowania układów osadniczych. Warszawa: Wydawnictwo Arkady. 
Markowski, T., \& Marszał, T. (2006). Metropolie, obszary metropolitalne, metropolizacja: problemy i pojęcia podstawowe. Warszawa: Komitet Przestrzennego Zagospodarowania Kraju PAN.

Miszewska, B. (1996). Struktura morfologiczna peryferyjnych osiedli Wrocławia. Prace Instytutu Geograficznego, Seria B: Geografia Społeczna i Ekonomiczna, 14, 53-61.

Miszewska, B. (2002). Ehemalige Dörfer als genetische Kerne im heutigen Stadtgefüge der Großstadt Breslau. Siedlungsforschung, 20, 293-306.

Miszewska, B., \& Szmytkie, R. (2015). Morphological processes in the spatial structure of the southern district of Wrocław city. Bulletin of Geography. Socio-economic Series, 27, 133-151. http://dx.doi.org/10.1515/bog-2015-0009

Morris, A.E.J. (2013). History of urban form before the industrial revolution. London: Routledge.

Motak, M. (2012). Historia rozwoju urbanistycznego Krakowa w zarysie. Kraków: Wydawnictwo Politechniki Krakowskiej.

Musiaka, Ł., Figlus, T., \& Szmytkie, R. (2020). Models of morphological transformations of centres of the largest Polish cities after World War II. European Planning Studies (online first). https://doi.org/10.1080/09654313.2020.1744529

Mydel, R. (1979). Rozwój struktury przestrzennej miasta Krakowa. Wrocław: Ossolineum.

Nagy, E., \& Timár, J. (2012). Urban restructuring in the grip of capital and politics: Gentrification in East-Central Europe. W: T. Csapó, \& A. Balogh (red.), Development of the Settlement Network in the Central European Countries (s. 121-135). Berlin - Heidelberg: Springer.

Newling, B.E. (1966). Urban Growth and Spatial Structure: Mathematical Models and Empirical Evidence. Geographical Review, 56(2), 213-225. https://doi.org/10.2307/212879

Pacione, M. (2001). Urban geography: A global perspective. New York: Routledge.

Rees, P.H. (1970). The factorial ecology of metropolitan Chicago. W: J.L. Berry, F.E. Horton, \& J.O. Abiodun (red.), Geographic perspectives on urban systems (s. 146-150). New Jersey: Prentice-Hall.

Riggleman, J.R. (1933). Building cycles in the United States, 1875-1932. Journal of the American Statistical Association, 28, 174-183. https://doi.org/10.1080/01621459.1933.10502255

Robson, B.T. (2012). Urban growth: an approach. London: Routledge.

Semotanová, E. (2010). Prostor města a jeho fázový růst v českých zemích od konce 19. století. Historická geografie (Historical Geography), 36(2), 225-254.

Sjöberg, G. (1960). The Pre-industrial City: Past, Present and Future. New York: Free Press.

Stanilov, K. (2007). Taking stock of post-socialist urban development: A recapitulation. W: K. Stanilov (red.), The post-socialist city: urban form and space transformations in Central and Eastern Europe after socialism (s. 3-17). Dordrecht: Springer.

Stewig, R. (1983). Die Stadt in Industrie-und Entwicklungsländern. Wien: Schöningh.

Sýkora, L. (1999). Changes in the internal spatial structure of post-communist Prague. GeoJournal, 49(1), 79-89. https://doi.org/10.1023/A: 1007076000411

Sýkora, L., \& Ouředníček, M. (2007). Sprawling post-communist metropolis: Commercial and residential suburbanization in Prague, Brno, the Czech Republic. The Geo Journal Library, 91, 209-233.

Szmytkie, R. (2011). Osiedla wiejskie w granicach administracyjnych dużego miasta (przykład Wrocławia). Studia Miejskie, 3, 159-186.

Szmytkie, R. (2019). Zmiany granic administracyjnych miast w Polsce w latach 1990-2017 i ich wpływ na wielkość zaludnienia. Konwersatorium Wiedzy o Mieście, 4(32), 19-34. http://dx.doi.org/10.18778/2543-9421.04.02

Szmytkie, R., \& Krzysztofik, R. (2019). The processes of incorporation and secession of urban and suburban municipalities: The case of Poland. Norsk Geografisk Tidsskrift - Norwegian Journal of Geography, 73(2), 110-127. https://doi.org/10.1080/00291951.2019.1604567 
Szymańska, D., Grzelak-Kostulska, E., \& Hołowiecka, B. (2006). Zmiany powierzchni i gęstości zaludnienia miast Polski w latach 1960-2003. W: J. Słodczyk, \& E. Szafranek (red.), Kierunki przekształceń struktury gospodarczej i społeczno-demograficznej miast (s. 341-353). Opole: Wydawnictwo Uniwersytetu Opolskiego.

Szymańska, D., Grzelak-Kostulska, E., \& Hołowiecka, B. (2009). Polish towns and the changes in their areas and population densities. Bulletin of Geography. Socio-economic Series, 11, 15-30. https://doi.org/10.2478/v10089-008-0018-2

Śleszyński, P. (2018). Problem podziału terytorialnego Obszaru Metropolitalnego Warszawy i wnioski dla Polski. Studia Regionalne i Lokalne, 2(72), 29-47. https://doi.org/10.7366/1509499527202

Tosics, I. (2006). Spatial restructuring in post-socialist Budapest. W: S. Tsenkova, \& Z. Nedovic-Budic (red.), The Urban Mosaic of Post-Socialist Europe (s. 131-150). Heidelberg: Physica-Verlag.

Ünlü, T. (2013). Thinking about urban fringe belts: a Mediterranean perspective. Urban Morphology, 17(1), 5-20.

Werwicki, A. (1973). Struktura przestrzenna średnich miast ośrodków wojewódzkich w Polsce. Wrocław: Zakład Narodowy im. Ossolińskich.

Whitehand, J.W. (1967). Fringe belts: a neglected aspect of urban geography. Transactions of the Institute of British Geographers, 41, 223-233. https://doi.org/10.2307/621338

Whitehand, J.W. (1972). Building cycles and the spatial pattern of urban growth. Transactions of the Institute of British Geographers, 56, 3955. https://doi.org/10.2307/621541

Whitehand, J.W.R. (1988). Urban fringe belts: development of an idea. Planning Perspectives, 3(1), 47-58. https://doi.org/10.1080/02665438808725651

Whitehand, J.W.R. (1994). Development cycles and urban landscapes. Geography, 79(1), 3-17.

Wilski, J. (1993). Warszawa. Rozwój przestrzenny. Warszawa: Oddział Warszawski Towarzystwa Urbanistów Polskich.

\section{Summary}

The primary aim of the study was to identify the process of territorial expansion and spatial development in large cities of Poland exemplified by Wrocław, Warsaw and Cracow. This denoted the gathering of information on changes in administrative boundaries as well as population in the cities referred to - from the $13^{\text {th }}$ century all the way through to modern times. The research hypothesis adopted was that cities expand their territories gradually, with each extension of administrative boundaries following a specific pattern and reflecting social and economic growth. The territorial development of a city (territorial change) thus relates to growth (change) in the administrative area, often in the form of expansion in relation to a widening of administrative boundaries, but with narrowing also possible. The spatial development of the city in turn follows the development of urbanised (especially built-up) areas both within the boundaries - and in the immediate vicinity - of the given city (with the development of suburban areas taking place). The latter does not usually result in a change of administrative boundaries. The study was inspired by observations on the specific nature of territorial growth in Wrocław and other large cities in Poland, for which analysis revealed some regularities to the settlement processes during different historical periods. Firstly, changes in the administrative boundaries 
of large cities followed a pulsatile pattern, with consecutive modifications alternating with periods of stability of variable length. Secondly, the territorial expansion of a city usually came after a period of dynamic social and economic growth both within existing boundaries and in the surrounding zone connected closely with the city and transformed under its influence. In turn, most longer periods in which boundaries were stable corresponded to periods of social and economic stagnation in the given city. Thirdly, the boundaries of cities changed when a certain climax point of population density was exceeded, and the city could no longer grow within its existing boundaries. Each extension contributed to an increase in the administered area and to population growth, albeit with population density decreasing considerably - in statistical terms - given the incorporation of new, less-urbanised areas offering free (potential) land for further urban growth. Fourthly, the sequence of development processes and their specific repeatability are cyclical in nature, and consecutive cycles are seen to end successive stages involving the extension of cities' administrative boundaries. A single cycle of changes in the administrative boundaries of the city consists of five basic phases. Phase I is the initial phase, which takes place at the moment of foundation of a city, or in the case of subsequent cycles - when there is extension of the city limits. During phase II the number of residents and population density within the city borders increase as a result of socio-economic growth. During phase III population density within the city boundaries continues to increase, and after reaching the limit of its growth potential the city sprawls to the nearest neighbourhood. During phase IV the impact of the city on its neighbourhood stimulates further development of the suburbs. This process may also often encompass suburban villages or smaller towns strongly connected with the city. During phase $V$ the functional link between the city and its neighbourhood (suburbs) is so strong that the administrative boundaries are extended to include suburban areas that represent a natural extension of the city. This contributes to an increase in area and population growth, as well as to a major decrease in population density within the new boundaries. This phase is at the same time the initial phase for the next cycle of a city's spatial and territorial development. The above described cyclical pattern of territorial growth concerns a specific group of cities - monocentric regional centres developing as a result of the influence of centripetal forces in the physicalism and functional approach. The presented research also reveals that the territorial development of a city is not always consistent with the actual directions of its spatial development. Significant extension of administrative boundaries was typical in the $20^{\text {th }} \mathrm{C}$. in large cities of Poland and other CEECs, and particularly common in the era of their centrally-planned economies, with a focus on planned urbanisation and industrialisation. Currently, cities in this region have entered a phase of dynamic suburbanisation that contributes to the significant development of urban areas, especially around large cities. 